\title{
Sistem Monitoring Kelembaban Tanah dan Kendali Pompa Air Menggunakan Arduino dan Internet
}

\author{
Husnun Nadzif ${ }^{1}$, Tatyantoro Andrasto ${ }^{2}$, dan Selamet Aprilian ${ }^{3}$ \\ Jurusan Teknik Elektro, Fakultas Teknik, Universitas Negeri Semarang \\ Kampus Sekaran, Gunungpati, Semarang, 50229, Indonesia \\ nadzief.99@students.unnes.ac.id ${ }^{1}$,tatyantoro@mail.unnes.ac.id ${ }^{2}$,selametaprilian@students.unnes.ac.id ${ }^{3}$
}

\begin{abstract}
Cultivation of eggplant plants requires special conditions, specifically with soil moisture about $80 \%-90 \%$. Factors that affect soil moisture on plant growth is water necessary. To meet the water necessary and keep the soil moisture can be done with watering the plants. Currently, the cultivation technique of eggplant is watered manually, then needed a system that is able to monitor of soil moisture and control waterpump to water the plants automatically so that soil moisture conditions can be maintained. This system uses Arduino as microcontroller, YL-69 soil moisture sensor, SIM80OL GSM module as data transmission, waterpump as sprinkler, and website as interface of the system because has advantage and convenience on the operation. The research method used the method of Research and Development. Test is done with Black Box test, Sensor Calibration test, and performance of the system test. Black Box test results indicate the functions in the website can be run properly, the sensor calibration test results indicate an average error of $2,2 \%$, and the performance testing system obtained percentage success of $100 \%$.
\end{abstract}

Keywords - soil moisture, Arduino, website, eggplant plants

\begin{abstract}
Abstrak- Pembudidayaan tanaman terong membutuhkan kondisi khusus yaitu dengan kelembaban tanah yang berkisar antara $80 \%-90 \%$. Faktor yang mempengaruhi kelembaban tanah pada perkembangan tanaman adalah kebutuhan air. Untuk memenuhi kebutuhan air dan menjaga kelembaban tanah dapat dilakukan melalui proses penyiraman. Saat ini teknik budidaya tanaman terong masih tergolong menggunakan cara penyiraman manual, maka diperlukan sebuah sistem yang mampu memantau kelembaban tanah dan mengontrol pompa air untuk menyiram tanaman secara otomatis agar kondisi kelembaban tanah dapat terjaga. Sistem ini menggunakan Arduino sebagai mikrokontroler, sensor kelembaban tanah YL-69, modul GSM SIM800L sebagai transmisi data, pompa air sebagai penyiram tanaman, serta website sebagai antarmuka sistem karena memiliki keunggulan dan kemudahan dalam pengoperasiannya. Metode penelitian yang digunakan adalah metode Penelitian dan Pengembangan. Pengujian yang dilakukan adalah dengan pengujian Black Box, uji Kalibrasi Sensor, dan Uji Kinerja Sistem. Hasil pengujian Black Box menunjukkan fungsi-fungsi dalam website dapat berjalan dengan baik, hasil pengujian kalibrasi sensor menunjukkan ratarata error sebesar $2,2 \%$, serta pada pengujian kinerja sistem didapatkan persentase keberhasilan sebesar $100 \%$.
\end{abstract}

Kata kunci- kelembaban tanah, Arduino, website, tanaman terong

\section{PENDAHULUAN}

Dalam pembudidayaan tanaman terong (Solanum Melongena L) kelembaban tanah harus berkisar $80 \%-90 \%$ [1]. Kelembaban berbanding terbalik dengan suhu/temperatur. Semakin tinggi suhu maka semakin rendah nilai kelembabannya begitu pula sebaliknya. Pengaruh kelembaban tanah pada tanaman hampir sama seperti suhu, karena pada dasarnya tumbuhan sangat membutuhkan air [2]. Jika kondisi kelembaban tanah tidak sesuai maka akan berpengaruh kurang baik terhadap pertumbuhan, produksi, dan kualitas buah. Hal ini erat kaitannya sebagai bahan dasar yang akan digunakan pada proses fotosintesis yang merupakan proses fisiologi tanaman untuk pembentukan karbohidrat [3]. Untuk memenuhi kebutuhan air dan menjaga kelembaban tanah dapat dilakukan melalui proses penyiraman.
Saat ini teknik budidaya khususnya pada tanaman terong masih dilakukan dengan cara penyiraman manual [4], hal ini memiliki beberapa kekurangan diantaranya: sulitnya mempertahankan kondisi kelembaban tanah yang dibutuhkan tanaman terong, kurang meminimalkan penggunaan tenaga manusia, menyita banyak waktu serta diperlukan cara pengendalian perangkat secara lebih efisien setiap saat dari mana saja [5]. Hal tersebut melatarbelakangi peneliti untuk membuat sebuah sistem yang mampu memantau (monitoring) dan mengontrol kondisi kelembaban tanah sesuai yang dibutuhkan tanaman terong dengan menggunakan jaringan internet dan diakses melalui website seperti pada penelitian [6] yaitu digunakan untuk remote monitoring pada alat elektronik yang ada di rumah. Internet dan website dapat menjadi sarana perantara untuk monitoring dan kendali pada tanaman karena selain mudah digunakan, internet dan website juga sudah sangat umum digunakan oleh masyarakat. Dengan 
menggunakan sistem pengendali jarak jauh, alat-alat elektronik dapat diketahui keadaannya menyala atau mati dan dapat diubah kondisinya [7].

Penelitian [8] tentang pembuatan alat monitoring penyiraman tanaman berdasarkan kelembaban tanah melalui SMS berbasis mikrokontroler merupakan salah satu cara yang digunakan dalam hal mengawasi serta merawat tanaman tetap dalam kondisi yang baik. Namun cara ini kurang efektif karena hanya melalui SMS untuk monitoring tanaman, sedangkan pada penelitian ini menggunakan website agar memudahkan untuk monitoring kelembaban tanah dan pengendalian pompa air juga dapat dilakukan secara otomatis atau manual. Kemudian penelitian [9] tentang pembuatan sistem yang ekonomis dan mudah dalam mengontrol sistem irigasi menggunakan Arduino. Namun sistem yang dibuat menggunakan modul WIFI ESP8266 dan pengguna harus tersambung WIFI untuk pengontrolan sistem irigasi, sedangkan penelitian ini transmisi data menggunakan modul GSM SIM800L dengan sinyal GSM yang terjangkau.

Tujuan penelitian ini adalah membuat sistem yang dapat melakukan monitoring dan menjaga kelembaban tanah pada tanaman terong. Sistem ini dilengkapi dengan sensor kelembaban tanah YL-69. Sensor tersebut bercatu daya antara $3,3 \mathrm{~V}$ hingga $5 \mathrm{~V}$ sehingga fleksibel untuk digunakan pada berbagai macam mikrokontroler [10]. Arduino digunakan sebagai output kendali sistem menggunakan pompa air untuk penyiraman tanaman seperti pada penelitian [11]. Sedangkan untuk mempermudah monitoring kelembaban tanah dan kendali pompa air, sistem ini juga dilengkapi dengan website yang digunakan untuk menampilkan informasi kelembaban tanah dan dapat diakses melalui HTTP untuk ditampilkan kepada user atau pemakai melalui web browser seperti pada penelitian [12] dan [13]. Dalam hal ini website digunakan sebagai antarmuka sistem monitoring kelembaban tanah dan kendali pompa air pada tanaman terong. Selain itu sistem ini juga menggunakan modul GSM SIM800L karena jangkauan yang lebih luas dan sebagai media transmisi data ke database melalui jaringan internet. Selain itu, penelitian ini tujuannya sama dengan penelitian [14] yaitu dapat digunakan dengan biaya rendah dan fleksibel untuk kontrol pertanian karena tidak menggunakan komponen yang mahal.

\section{Metode PEnelitian}

Prosedur penelitian ditunjukkan pada Gambar 1. Pada tahap perancangan alat dibagi menjadi dua bagian yaitu perancangan perangkat dan website. Kemudian langkah selanjutnya adalah pembuatan perangkat sistem dan membangun website. Setelah itu sistem di uji coba jika tidak berhasil maka dilakukan analisa kegagalan tindakan perbaikan, jika berhasil maka dilakukan pengambilan data pengujian. Tahap pengujian dan pengambilan data dilakukan untuk mengetahui kualitas sistem yang dibuat. Pengujian dalam penelitian ini dilakukan dengan metode Black Box yaitu menguji semua fungsi tombol yang ada pada website, uji kalibrasi sensor yaitu menguji nilai error pada sensor kelembaban tanah YL-69, serta uji kinerja sistem yaitu menguji kinerja pengiriman data ke dalam web server. Diagram blok sistem ditunjukkan pada Gambar 2.
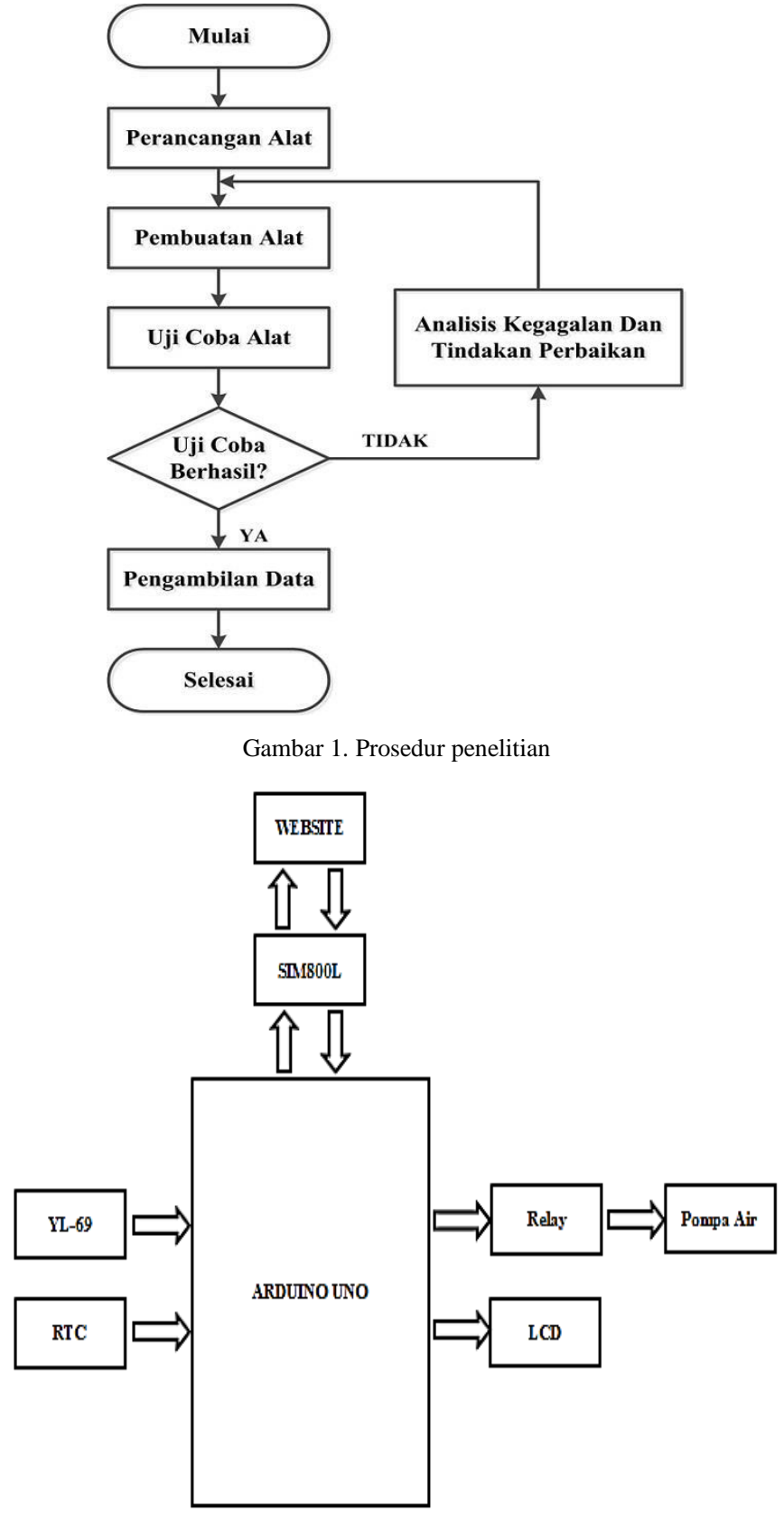

Gambar 2. Diagram blok sistem

Sistem yang dibuat menggunakan mikrokontroler Arduino Uno sebagai pusat kendali. Input dari sistem yaitu sensor Soil Moisture YL-69 dan Module RTC (Real Time Clock). Sedangkan output terdiri dari LCD 16x2 dan Pompa Air DC yang tersambung dengan selang air dan sprinkler sebagai penyemprot tanaman. Antarmuka yang digunakan berbasis website dengan transmisi data dari Arduino ke dalam database website menggunakan Modul GSM SIM800L. Kontrol pompa air dapat menggunakan dua mode yaitu mode otomatis dan mode manual. Pada mode otomatis pompa air akan hidup ketika kelembaban tanah kurang dari $80 \%$ dan akan mati ketika kelembaban tanah mencapai $90 \%$. Pada mode manual pompa air dihidupkan dan dimatikan melalui tombol pada website. 


\section{HASIL DAN PEMBAHASAN}

\section{A. Antarmuka Mode Otomatis}

Dalam antarmuka mode otomatis, pengguna dapat mengetahui kelembaban tanah dalam persen, status pompa air hidup atau mati, tanaman yang digunakan, kelembaban tanah yang diperlukan tanaman serta dapat mengubah ke dalam mode manual. Dalam mode otomatis seperti ditunjukkan pada Gambar 3, kelembaban tanah yang diperlukan tanaman terong adalah $80 \%-90 \%$. Jika kelembaban tanah yang terbaca oleh sensor kurang dari $80 \%$ maka pompa air akan hidup sampai kelembaban tanah mencapai $90 \%$ dan pompa akan mati secara otomatis.

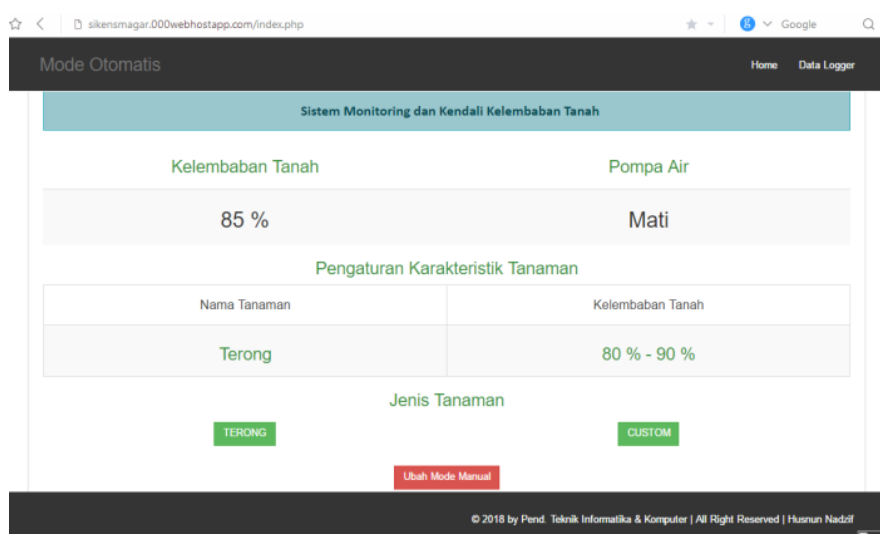

Gambar 3. Antarmuka Mode Otomatis

\section{B. Antarmuka Mode Manual}

Dalam antarmuka mode manual, pengguna dapat menekan tombol Pompa On untuk menghidupkan pompa air dan Pompa Off untuk mematikan pompa air. Pengguna juga dapat beralih ke dalam mode otomatis dengan menekan tombol Ubah Mode Otomatis. Dalam mode manual seperti ditunjukkan pada
Gambar 4, pengguna dapat memantau kelembaban tanah dan dapat menghidupkan atau mematikan pompa air secara manual dengan menekan tombol Pompa On atau Pompa Off.

\section{Antarmuka Data Logger}

Dalam antarmuka Data Logger, pengguna dapat melihat data yang terekam yaitu data waktu, data kelembaban tanah, status pompa hidup atau mati, mode yang digunakan setiap empat menit sekali perekaman. Selain menampilkan informasi seperti ditunjukkan pada Gambar 5, data dalam bentuk tabel tersebut juga dapat di unduh dengan menekan Downlod Data. Data tersebut akan terunduh dengan fomat Microsoft Excel.

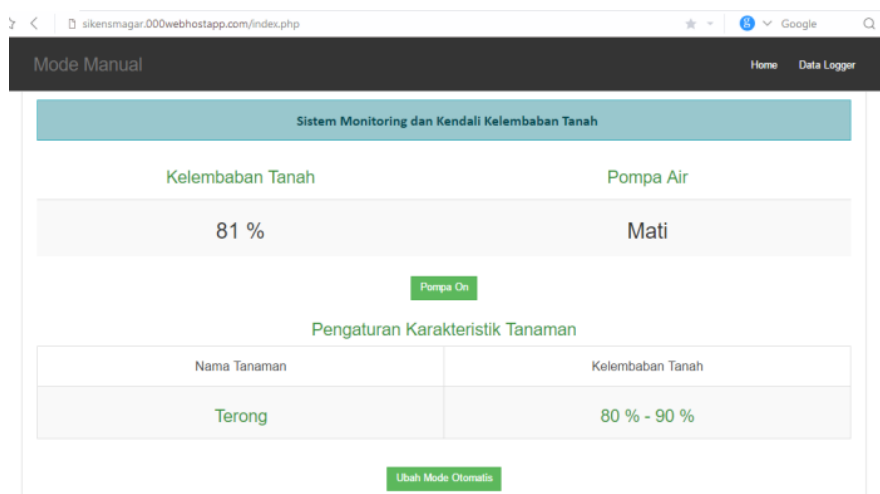

Gambar 4. Antarmuka Mode Manual

\section{Hasil Pembuatan Alat}

Gambar 6 merupakan bentuk fisik (elektronik) alat yang dirancang. Gambar 7 merupakan media tanaman terong skala 1x1 meter persegi yang ditanami 6 tanaman terong. Sensor kelembaban tanah ditancapkan di sekitar tanaman terong dan di atas tanaman terong dipasang sprinkler yang tersambung dengan pompa air. Jika pompa air hidup maka sprinkler akan menyemprotkan air ke arah tanaman terong secara merata.
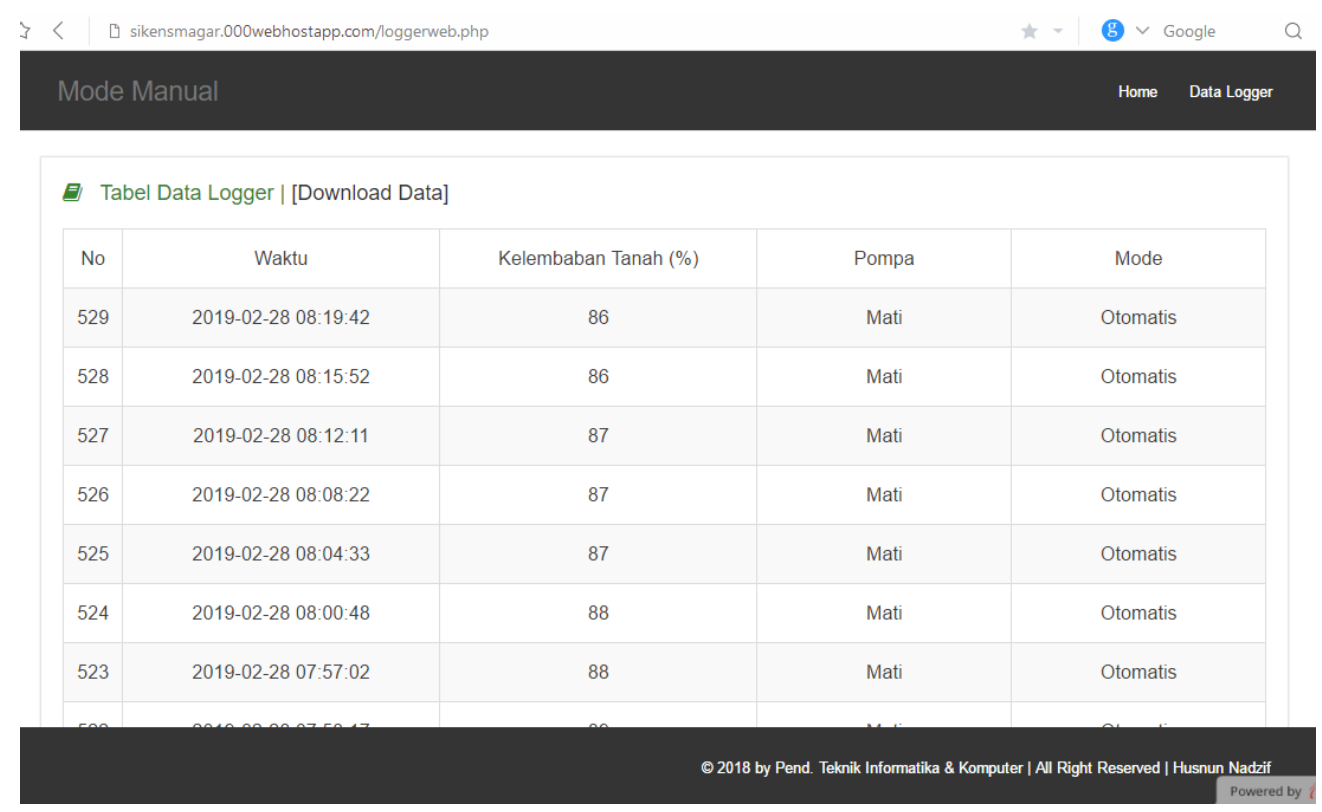

Gambar 5. Antarmuka Data Logger 


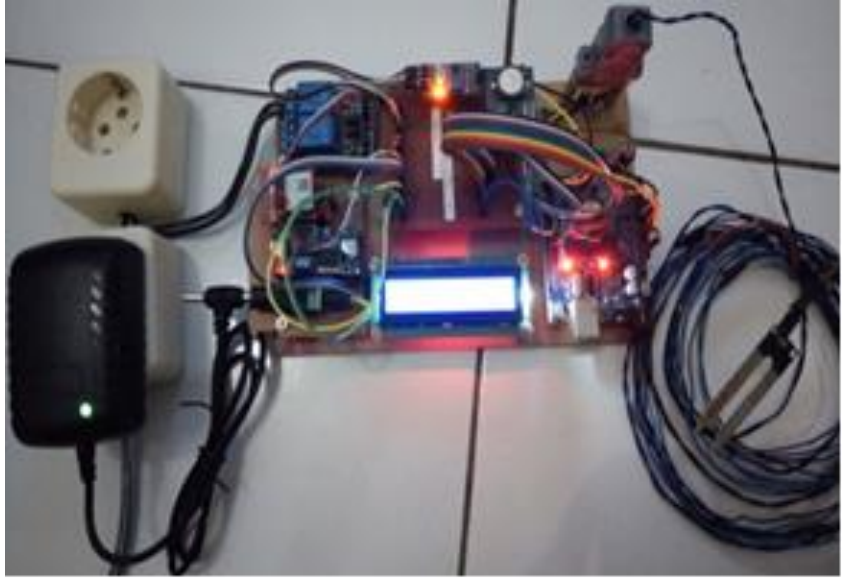

Gambar 6. Hasil pembuatan alat

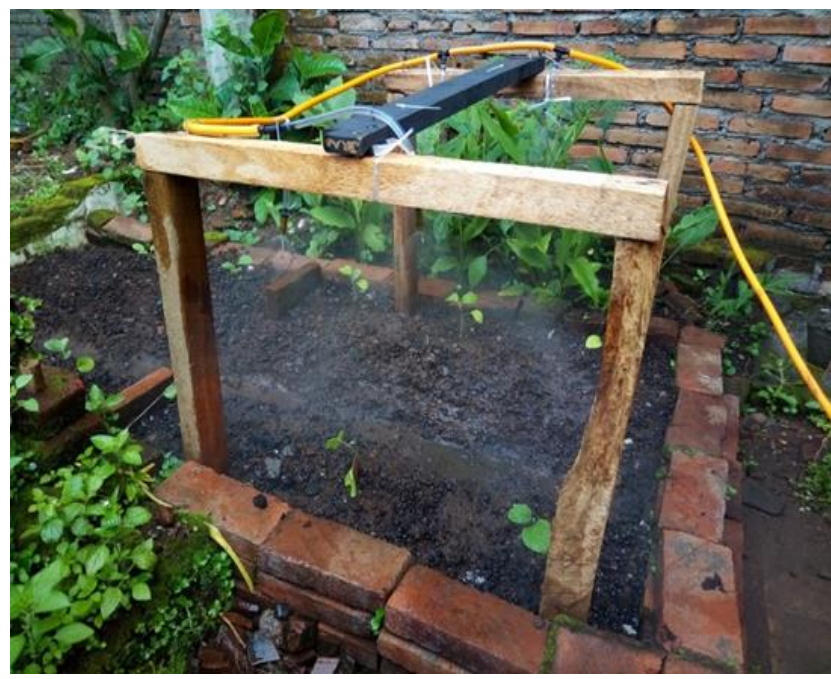

Gambar 7. Hasil pembuatan media tanaman terong skala 1x1 meter persegi

\section{E. Hasil Pengujian}

\section{1) Hasil Pengujian Black Box}

Pengujian Black Box meliputi pengujian pada mode otomatis dan mode manual. Hasil pengujian Black Box pada kedua mode, didapatkan bahwa semua komponen pada website mode otomatis dan mode manual berjalan dengan baik sesuai dengan fungsinya masing-masing.

2) Hasil Pengujian Kalibrasi Sensor

Pengujian kalibrasi sensor dilakukan dengan cara membandingkan pembacaan Soil Moisture Meter dengan pembacaan sensor Soil Moisture YL-69 pada lima sampel tanah dengan kelembaban berbeda. Hasil pengujian ini mendapatkan hasil seperti pada Tabel I. Rata-rata error sensor adalah sebesar $2,2 \%$.
TABEL I. Hasil Pengujian Kalibrasi Soll Moisture Meter DENGan SENSOR SOIL MOISTURE YL-69

\begin{tabular}{|c|c|c|c|}
\hline $\begin{array}{c}\text { Sampel } \\
\text { Tanah }\end{array}$ & $\begin{array}{c}\text { Soil Moisture } \\
\text { Meter (\%) }\end{array}$ & $\begin{array}{c}\text { Sensor Soil } \\
\text { Moisture YL-69 } \\
(\boldsymbol{\%})\end{array}$ & Error (\%) \\
\hline A & 28 & 27 & 1 \\
\hline B & 48 & 46 & 2 \\
\hline C & 58 & 55 & 3 \\
\hline D & 70 & 72 & 2 \\
\hline E & 93 & 90 & 3 \\
\hline \multicolumn{3}{|c|}{ Total Nilai Error } \\
\hline \multicolumn{3}{|c|}{ Rata-Rata Nilai Error } \\
\hline
\end{tabular}

3) Hasil Pengujian Kinerja Sistem

Pengujian kinerja sistem meliputi pengujian mode otomatis dan mode manual. Pengujian kinerja sistem pada mode otomatis dengan mengirimkan data sensor ke web server didapatkan presentase keberhasilan sebesar $100 \%$. Sedangkan pada mode manual dengan menghidupkan dan mematikan pompa air sebanyak 20 kali dan didapatkan presentase keberhasilan sebesar $100 \%$.

Tabel II merupakan hasil pengujian kinerja sistem pada mode otomatis. Waktu yang dibutuhkan untuk menaikkan kelembaban tanah dari 63\% sampai dengan 93\% adalah sekitar 27 menit (1620 detik) yaitu dari pukul 15:57:01 sampai dengan pukul 16:24:13. Artinya, untuk menaikkan 1\% kelembaban tanah membutuhkan waktu sekitar 54 detik atau 0,9 menit.

\section{F. Pembahasan}

Penelitian pengembangan monitoring kelembaban tanah dan kendali pompa air menggunakan Arduino dan internet pada tanaman terong dirancang dan dikembangkan berdasarkan penelitian terdahulu [8], [9], dan [15]. Penggunaan web server sebagai penyimpanan data dan penggunaan antarmuka website yang memudahkan menampilkan dan mengendalikan perangkat telah diakomodir dalam penelitian ini sama seperti penelitian [9] dan [15]. Penggunaan modul SIM800L meningkatkan jarak jangkauan dan kemudahan akses monitoring bila dibandingkan menggunakan SMS [8], WIFI module [9], maupun koneksi Ethernet [15].

\section{IV.PENUTUP}

Sistem monitoring kelembaban tanah dan kendali pompa air menggunakan Arduino dan internet yang menggunakan mikrokontroller Arduino Uno dan modul GSM SIM800L, web server sebagai media penyimpanan data, dan website sebagai antarmuka untuk memantau kelembaban tanah dan mengendalikan pompa air berjalan dengan baik. Penelitian dapat dikembangkan dengan menambahkan sensor lain agar lebih kompleks dan penggunaan algoritma seperti Fuzzy. 
TABEL II. Hasil Pengujian KinerJa Sistem Pada Mode Otomatis

\begin{tabular}{|c|c|c|c|c|c|}
\hline \multirow{2}{*}{ No } & \multirow{2}{*}{ Waktu } & \multirow{2}{*}{ Kelembaban Tanah ( $\%)$} & \multirow{2}{*}{ Status Pompa Air } & \multicolumn{2}{|c|}{ Keterangan } \\
\hline & & & & Berhasil & Tidak \\
\hline 1 & 2019-02-26 15:57:01 & 63 & Hidup & $\checkmark$ & \\
\hline 2 & 2019-02-26 16:01:04 & 67 & Hidup & $\checkmark$ & \\
\hline 3 & 2019-02-26 16:06:09 & 72 & Hidup & $\checkmark$ & \\
\hline 4 & 2019-02-26 16:07:10 & 77 & Hidup & $\checkmark$ & \\
\hline 5 & 2019-02-26 16:12:12 & 83 & Hidup & $\checkmark$ & \\
\hline 6 & 2019-02-26 16:16:41 & 86 & Hidup & $\checkmark$ & \\
\hline 7 & 2019-02-26 16:20:25 & 89 & Hidup & $\checkmark$ & \\
\hline 8 & 2019-02-26 16:24:13 & 93 & Mati & $\checkmark$ & \\
\hline 9 & 2019-02-26 16:27:55 & 94 & Mati & $\checkmark$ & \\
\hline 10 & 2019-02-26 16:31:40 & 94 & Mati & $\checkmark$ & \\
\hline 11 & 2019-02-26 16:35:28 & 94 & Mati & $\checkmark$ & \\
\hline 12 & 2019-02-26 16:39:15 & 94 & Mati & $\checkmark$ & \\
\hline 13 & 2019-02-26 16:43:00 & 93 & Mati & $\checkmark$ & \\
\hline 14 & 2019-02-26 16:46:45 & 93 & Mati & $\checkmark$ & \\
\hline 15 & $2019-02-26$ 16:50:30 & 92 & Mati & $\checkmark$ & \\
\hline 16 & 2019-02-26 16:54:17 & 92 & Mati & $\checkmark$ & \\
\hline 17 & 2019-02-26 16:58:02 & 92 & Mati & $\checkmark$ & \\
\hline 18 & 2019-02-26 17:01:47 & 91 & Mati & $\checkmark$ & \\
\hline 19 & 2019-02-26 17:05:38 & 91 & Mati & $\checkmark$ & \\
\hline 20 & 2019-02-26 17:09:23 & 90 & Mati & $\checkmark$ & \\
\hline 21 & 2019-02-26 17:13:17 & 90 & Mati & $\checkmark$ & \\
\hline 22 & 2019-02-26 17:17:02 & 90 & Mati & $\checkmark$ & \\
\hline 23 & 2019-02-26 17:20:46 & 89 & Mati & $\checkmark$ & \\
\hline 24 & 2019-02-26 17:24:32 & 89 & Mati & $\checkmark$ & \\
\hline 25 & 2019-02-26 17:28:16 & 89 & Mati & $\checkmark$ & \\
\hline 26 & 2019-02-26 17:32:01 & 89 & Mati & $\checkmark$ & \\
\hline 27 & $2019-02-26$ 17:35:46 & 88 & Mati & $\checkmark$ & \\
\hline 28 & 2019-02-26 17:39:31 & 88 & Mati & $\checkmark$ & \\
\hline 29 & 2019-02-26 17:43:16 & 88 & Mati & $\checkmark$ & \\
\hline 30 & 2019-02-26 17:47:01 & 88 & Mati & $\checkmark$ & \\
\hline 31 & 2019-02-26 17:50:46 & 87 & Mati & $\checkmark$ & \\
\hline 32 & 2019-02-26 17:54:31 & 87 & Mati & $\checkmark$ & \\
\hline
\end{tabular}

\section{REFERENSI}

[1] B. Cahyono, Untung Besar dari Terung Hibrida, Edisi Pertama, Jakarta: Pustaka Mina, 2016.

[2] L. A. Lomo, "Smart Greenhouse Berbasis Mikrokontroler Arduino Mega 2560 Rev 3," Program Studi Teknik Elektro, Universitas Sanata Dharma Yogyakarta, 2016.

[3] K. Amaru, E. Suryadi, N. Bafdal, and F. P. Asih, "Kajian Kelembaban Tanah dan Kebutuhan Air Beberapa Varietas Hibrida DR UNPAD," Jurnal Keteknikan Pertanian, vol. 1, no. 1, pp. 107-115, 2013.

[4] M. D. Syamsiar, M. Rivai, and Suwito, "Rancang Bangun Sistem Irigasi Tanaman Otomatis menggunakan Wireless Sensor Network," Jurnal Teknik ITS, vol. 5, no. 2, pp. 261-266, 2016.

[5] C. Das, M. Sanaullah, H. Sarower, and M. Hassan, "Development of a Cell Phone based Remote Control System: an Effective Switching System for Controlling Home and Office Appliances," International Journal of Electrical \& Computer Sciences IJECS, vol. 9, no. 10, pp. 37-43, 2009.

[6] M. Sahani, S. K. Rout, and A. Mandai, "Remote Monitoring in Home Automation using Low Cost Microcontroller," IEEE Interational Conference on Communication and Signal Processing, pp. 925-929, 2014.

[7] P. Mega and T. Andrasto, "Sistem Pengendali dan Monitoring Peralatan Listrik Rumah Tangga Melalui Web," Edu Komputika Journal, vol. 3, no. 1, pp. 27-32, 2016.

[8] C. P. Yahwe, Isnawaty, and L. F. Aksara, "Rancang Bangun Prototype Sistem Monitoring Kelembaban Tanah Melalui SMS Berdasarkan Hasil Penyiraman Tanaman Studi Kasus Tanaman Cabai dan Tomat," SemanTIK, vol. 2, no. 1, pp. 97-110, 2016.
[9] P. Singh and S. Saikia, "Arduino-Based Smart Irrigation Using Water Flow Sensor, Soil Moisture Sensor, Temperature Sensor and ESP8266 WIFI Module," in IEEE Region 10 Humanitarian Technology Conference, pp. 1-4, 2016.

[10] E. N. Prasetyo, "Prototype Penyiraman tanaman Persemaian dengan Sensor Kelembaban Tanah Berbasis Arduino,” Jurusan Teknik Elektro, Universitas Muhammadiyah Surakarta, 2015.

[11] CM. Devika, B. Karthika, and S. Vijayalekshmy, "Automatic Plant Irrigation System using Arduino," in IEEE International Conference on Circuits and System, pp. 384-387, 2017.

[12] I. A. Saputro, J. E. Suseno, and E. Widodo, "Rancang Bangun Sistem Pengaturan Kelembaban Tanah Secara Real Time Menggunakan Mikrokontroler dan Diakses di WEB," Youngster Physics Journal, vol. 6, no. 1, pp. 40-47, 2017.

[13] Rasmila, "Evaluasi Website dengan Menggunakan System Usability Scale (SUS) pada Perguruan Tinggi Swasta di Palembang," Jurnal Sistem Informasi, vol. 2, no. 1, pp. 108-121, 2018.

[14] N. M. Z. Hashim, S. R. Mazlan, M. Z. A. Abd Aziz, A. Salleh, A. S. Ja'afar, and N. R. Mohamad, "Agriculture Monitoring System: A Study," Jurnal Teknologi (Sciences \& Engineering), vol. 77, no. 1, pp. 53-59, 2015.

[15] D. Kurnia, and A. A. Suprianto, "Rancang Bangun Prototipe Gardening Smart System (GSS) untuk Perawatan Tanaman Anggrek Berbasis Web," SIMETRIS, vol. 7, no. 1, pp. 191-198, 2016. 